\title{
СОЦІАЛЬНИЙ ЗАХИСТ ПРАЦІВНИКІВ ОРГАНІВ ВНУТРІШНІХ СПРАВ ЯК ГАРАНТІЯ СОЦІАЛЬНОЇ БЕЗПЕКИ ДЕРЖАВИ
}

Іванов І. В., Князькова Л. М., Хайлова Т. В.

Стаття присвячена дослідженню проблем соціального захисту працівників органів внутрішніх справ як складової соціальної безпеки держави. здійснено аналіз нормативних актів, що регулюють порядок перерахунку пенсій колишнім працівникам міліції у зв'язку з підвищення грошового утримання поліцейським. Запропоновано зміни до нормативних актів, що регулюють прирівнювання посад колишніх працівників міліції до посад поліцейських. Автор обгрунтовує необхідність правового регулювання порядку нарахування та розмірів премій, які враховуються при обчисленні та перерахунку пенсій.

Ключові слова: соціальна безпека держави, працівники органів внутрішніх справ, працівники поліціі, національна безпека, сочіальний захист.

Статья посвящена исследованию проблем социальной защиты работников органов внутренних дел как составляющей социальной безопасности государства. Анализируются нормативные акты, регулирующие порядок перерасчета пенсий бывшим работникам милиции в связи с повышение денежного содержания полицейским. Предлагаются изменения в нормативные акты, регулирующие приравнивание должностей бывших работников милиции $\kappa$ должностям полицейских. Автором обосновывается необходимость правового регулирования порядка начисления и размеров премий, которые учитываются при исчислении и перерасчете пенсий.

Ключевые слова: социальная безопасность государства, работники органов внутренних дел, работники полиции, национальная безопасность, социальная защита.

Ivanov I. V., Knyazkova L. M., Khailova T. V. Social security of law enforcement employees as a guarantee of the social security of the state

The article deals with the research of the issues related to the social security of law enforcement employees. Since the social security of law enforcement employees is a component of the social security of the state, the concept of social security as such is considered. It is argued that social security is an integral concept signifying the position and the ability of the state and the society to ensure efficient functioning of the social sphere, prevent destructive phenomena and processes, preserve and develop conditions, means and ways for people's socialization, uphold people's way of living in the society and the state, ensure their welfare, inalienable rights and freedoms, as well as their spiritual and moral values. The author emphasizes the significant role of law enforcement agencies in accomplishing those important tasks.

In the author's opinion, when assigning a wide range of duties to law enforcement employees for protecting public order, ensuring public security, combating crime, adequately protecting the life and health of individuals against unlawful encroachments, the state is obliged to provide them with adequate social

(с Іванов І. В., Князькова Л. М., Хайлова Т. В., 2020 security to enhance the efficiency of their law enforcement activities.

The main guarantee of police employees' social security is their pay and allowances consisting of salaries, special rank salaries, additional monthly types of pay and allowances (one-off payments, benefits and allowances of permanent character), bonuses and lump sum payments. The statutory provisions are analyzed that entitle former police employees to increased pensions in connection with the allocation of new salaries, special rank salaries and superannuation allowances, since the recalculation of pensions as of January 01, 2016, for the former members of the commanding staff and rank-and-file personnel of the law enforcement agencies is carried out on an equal basis with the police employees of the present-day National Police taking into account the corresponding salaries, special rank salaries, superannuation allowances, additional monthly types of pay and allowances (benefits, allowances, one-off payments) and bonuses. The issue is investigated of equating the posts of the commanding staff and rank-and-file personnel of the law enforcement agencies of Ukraine, who are entitled to pensions or who receive pensions under the Law of Ukraine "On Provision of Pension for Persons Discharged from Military Service and That for Some Other Persons", to the posts of police officers of the present-day National Police.

The author has determined that the issue of equating the posts of former police officers with the posts of the police officers of the present-day National Police and recalculating their pensions requires a detailed study, because it is not only a matter of fairness in the distribution of social benefits, but also a matter of the legality and the validity of payments from the Pension Fund of Ukraine, which is formed both from obligatory contributions of business entities and citizens, and from funds of the State Budget of Ukraine intended for payment of pensions to servicemen and some other categories of persons.

The author proposes to tie the posts of former police officers, who served at higher education institutions of the Ministry of Internal Affairs (an academy, a university, an institute), with the posts of the apparatus of the present-day National Police of Ukraine.

Due to the fact that nowadays most of the police employees' pay and allowances is made up of benefits, allowances and bonuses, it is proposed to increase salaries, special rank salaries, and to raise superannuation allowance in percentage terms. With regard to bonuses and benefits, the amount and the payment procedure thereof require legal regulation depending on the contribution of each employee to the performance of a police body.

Key words: social security of the state, law enforcement employees, police employees, national security, social security.

Постановка проблеми. 3 моменту проголошення незалежності України і до сьогоднішнього дня не припиняється законотворча діяльність щодо нормативно-правового регулювання питань соціального захисту працівників правоохоронних органів. Разом із тим, 
таке охоплення законодавчим регулюванням правових засад соціального захисту правоохоронців зовсім не виключає актуальності проблеми, недосконалості нормативно-правової бази щодо реформування системи соціального захисту працівників правоохоронних органів та механізму реалізації. Масовими стали спори співробітників органів внутрішніх справ з органами пенсійного фонду [1, с. 162]. Актуальним $є$ питання щодо прирівнювання посад осіб начальницького і рядового складу органів внутрішніх справ України (міліції), які мають право на пенсійне забезпечення або одержують пенсію на умовах Закону України «Про пенсійне забезпечення осіб, звільнених з військової служби, та деяких інших осіб» до посад поліцейських. Потребує детального аналізу механізм розрахунку середніх розмірів премій, виплачених поліцейським у січні 2016 року, адже розмір пенсій колишнім працівникам міліції після перерахунку у більшій мірі залежить не від посадового окладу, окладів за спеціальним званням та надбавки вислугу років, а від середніх розмірів премій, виплачених поліцейським за січень 2016. У результаті такого обчислення розміри пенсій після перерахунку у пенсіонерів, які мають однакову вислугу, звання і посаду, але проходили службу у різних підрозділах міліції відрізняються настільки, що така різниця складає половину, а в деяких випадках і більш, пенсії.

Аналіз останніх досліджень і публікацій. Дослідженням проблем теоретико-практичних аспектів правового регулювання соціального захисту працівників поліції (міліції) займалися провідні вчені, зокрема: В.М. Андріїв, Н.Б. Болотіна, В.С. Венедиктов, С.В. Венедиктов, С.В. Вишновецька, М.В. Вітрук, Л.Д. Воєводін, М.І. Іншин, М.М. Клемпарський, К.Ю. Мельник, C.М. Приліпко, П.Д. Пилипенко, Г.І. Чанишева, В.І. Щербіна та ін.

Формування цілей. Метою цієї статті $\epsilon$ проведення аналізу існуючої системи правового регулювання та практики перерахунку пенсій колишнім працівникам міліції у зв'язку з підвищенням грошового забезпечення поліцейських в Україні та вироблення пропозицій щодо вдосконалення порядку здійснення такого перерахунку.

Матеріали та методи дослідження. Дослідження проводилось на підставі аналізу нормативних актів, які регулюють соціальний захист працівників органів внутрішніх справ, наукової літератури та практики застосування законодавства. Наукове дослідження побудовано на підставі застосування загального системно-структурного методу, основні елементи якого забезпечили розв'язання поставлених задач. В основі системи методології наукового аналізу соціального захисту працівників органів внутрішніх справ покладено такі методи:

- діалектичний - за допомогою цього методу проаналізовано порядок перерахунку пенсій колишнім працівникам міліції та встановлено сучасний стан проблеми;

- системний - дозволив здійснити об'єктивне дослідження відповідного окресленого предмета, зокрема, дав змогу дослідити порядок прирівнювання посад працівників міліції до посад поліцейських. Крім того, використовувались такі логічні методи як дедукція, індукція, аналогія, синтез.

Виклад основного матеріалу. Потреба реформування базових соціальних інститутів українського суспільства на шляху до європейського майбутнього у поєднанні із необхідністю протистояти військовій агресї̈ поставили українське суспільство перед найбільшими викликами та загрозами. 3 одного боку, драматичні події, що відбуваються на сході України, сприяють згуртуванню і самоусвідомленню української політичної нації, розкривають великий потенціал громадянської самоорганізації, що існує в українському суспільстві. 3 іншого - ці ж самі події загострюють питання забезпечення всіх складових національної безпеки держави, зокрема соціальної.

Соціальній захист працівників органів внутрішніх справ виступає одним з елементів соціальної безпеки держави. Тому для визначення місця соціального захисту працівників органів внутрішніх справ у соціальній безпеці держави неможливо без визначення «соціальної безпеки».

У науці відсутній єдиний підхід до визначення поняття соціальної безпеки. Деякі автори трактують соціальну безпеку як синонім національної безпеки в цілому, оскільки з їі допомогою забезпечується цілісність і стійкість всього суспільства. I тоді всі інші види безпеки, такі як економічна, політична, технологічна тощо охоплюються нею як складові частини [2, с. 14]. 21 червня 2018 року було прийнято Закон України «Про національну безпеку України», в якому національну безпеку України визначено як захищеність державного суверенітету, територіальної цілісності, демократичного конституційного ладу та інших національних інтересів України від реальних та потенційних загроз [3]. В цьому законі не вказується про соціальну безпеку. Але ч. 4 ст. 3 закріплено, що державна політика у сферах національної безпеки і оборони спрямовується на забезпечення воєнної, зовнішньополітичної, державної, економічної, інформаційної, екологічної безпеки, тощо.

Низький рівень соціальної безпеки суспільства визначається слабкою правовою та договірною захищеністю його членів, песимістичними перспективами щодо соціальної, трудової та інноваційної активності громадян, високим рівнем бідності, безробіття, злочинності та нерівності, а також зростанням корупції та тіньових відносин. Ці негативні явища підривають національну єдність та консолідованість української нації, знецінюють перспективи на успішне майбутнє і держави, і людини [4, с. 12]. Соціальна безпека - це інтегральне поняття, що позначає стан і здатність держави і суспільства до ефективного функціонування соціальної сфери, запобігання деструктивним явищам і процесам, збереження і розвитку умов, засобів і способів соціалізації людей, дотримання в суспільстві і державі їх способу життя, добробуту, невід'ємних прав і свобод, духовно-моральних цінностей. Соціальна безпека при реалізації права на соціальний захист виражається у всебічній державній та громадській підтримці вразливих верств населення; подоланні бідності; забезпеченні достатнього життєвого рівня, до якого включаються: мінімальний розмір заробітної плати, мінімальний розмір пенсії, неоподаткований мінімум доходів громадян, розміри державної соціальної допомоги та інших соціальних виплат, висока якість надання соціальних послуг та соціального обслуговування [5, с. 26]. Таким чином, для забезпечення соціальної безпеки у суспільстві держава повинна проводити ефективну соціальну політику з метою забезпечення прав людини при здійсненні трудової діяльності, 
реалізації права на соціальний захист, а також культурний і духовний розвиток.

Здійснювані в Україні глибокі державно-правові та соціально-економічні перетворення вимагають подальшого зміцнення законності та правопорядку, забезпечення безпеки особи, належного захисту та охорони конституційних прав, свобод і законних інтересів людини і громадянина. Значну роль у здійсненні цих важливих завдань відіграють органи внутрішніх справ. Покладаючи на працівників ОВС широке коло обов'язків щодо охорони громадського порядку, забезпечення громадської безпеки, боротьби із злочинністю, належної охорони життя та здоров'я особи від протиправних посягань, держава зобов'язана забезпечити їх належним захистом для підвищення ефективності їх правоохоронної діяльності.

На даний час система соціального захисту ОВС України ґрунтується на обтяженій і заплутаній законодавчій базі, деякі норми носять чисто декларативний характер, немає механізмів запровадження окремих норм у життя, у Пенсійному фонді України не вистачає коштів для пенсійного забезпечення правоохоронців.

Для концептуального дослідження правового регулювання пенсійного забезпечення поліцейських важливе значення має пенсійне забезпечення колишніх працівників міліції, адже вони впродовж майже 25 років незалежної України дбали про безпеку громадян і держави [6, с. 50].

У зв'язку з підвищенням грошового забезпечення поліцейським актуальним $є$ питання про розмір грошового забезпечення, яке враховується при перерахунку пенсій колишнім працівникам органів внутрішніх справ. Важливим аспектом при цьому $\epsilon$ те, до якої посади поліцейського прирівняна посада осіб начальницького і рядового складу органів внутрішніх справ України (міліції). Таке прирівнювання здійснено Міністерством внутрішніх справ України Наказом від 17.02.2017 № 138 «Про затвердження Переліку посад осіб начальницького і рядового складу органів внутрішніх справ України (міліції), які мають право на пенсійне забезпечення або одержують пенсію на умовах Закону України «Про пенсійне забезпечення осіб, звільнених з військової служби, та деяких інших осіб», що прирівнюються посадам поліцейських» [7]. Згідно зазначеного Переліку посади осіб начальницького та рядового складу органів внутрішніх справ (міліції), які проходили службу в навчальних закладах системи МBC прирівняні до посад поліцейських в залежності від рівня навчального закладу. Так посади осіб начальницького та рядового складу органів внутрішніх справ (міліції), які проходили службу в Національної академії внутрішніх справ та Національних університетах внутрішніх справ (юридичному ліцеї) прирівняні до посад поліцейських апарату Національної поліції; посади - в державних університетах внутрішніх справ - до посад поліцейських апарату Головного управління Національної поліції в місті Києві, а посади осіб начальницького та рядового складу органів внутрішніх справ (міліції) в юридичних інститутах - до посад поліцейських апарату Головних управлінь Національної поліції. Таким чином, посади осіб начальницького та рядового складу органів внутрішніх справ (міліції), які проходили службу в Національній академії внутрішніх справ, національних університетах внутрішніх справ, державних університетах внутрішніх справ та юридичних інститутах прирівняні до посад поліцейських в органах Національної поліції різного рівня від апарату Національної поліції до апарату Головних управлінь Національної поліції, стройових підрозділів поліції. Прирівнювання посад працівників міліції до посад поліцейських має важливе значення та потребує вивчення, оскільки нормативні акті, які регулюють такий порядок мають суттєві розбіжності. Так, зокрема, відповідно до Порядку проведення перерахунку пенсій, призначених відповідно до Закону України «Про пенсійне забезпечення осіб, звільнених з військової служби, та деяких інших осіб», затвердженого постановою Кабінету Міністрів України від 13.02.2008 № 45 [8], особам начальницького і рядового складу органів внутрішніх справ (міліції) перерахунок пенсії з 1 січня 2016 р. проводиться з розміру грошового забезпечення за прирівняною посадою поліцейського, враховуючи оклади за посадою, спеціальним званням, відсоткову надбавку за вислугу років, щомісячні додаткові види грошового забезпечення (надбавки, доплати, підвищення) та премії у розмірах, установлених законодавством, з якого було сплачено єдиний внесок на загальнообов'язкове державне соціальне страхування, за січень 2016 р. відповідно до постанови Кабінету Міністрів України від 11.11.2015 № 988 «Про грошове забезпечення поліцейських Національної поліції» [9]. Отже, розмір премії визначається у середніх розмірах, що фактично виплачені за відповідною посадою (посадами) поліцейського за січень 2016 року.

Наказом МВС України № 601 від 13.07.2018 року затверджено Перелік посад поліцейських і військовослужбовців Національної гвардії України, які рівнозначні (аналогічні) посадам, що можуть бути заміщені поліцейськими і військовослужбовцями в державних органах, установах та організаціях [9]. Згідно цього Переліку посади у вищих навчальних закладах системи МBC України незалежно від рівня навчального закладу (академія, університети, інститути) $є$ рівнозначними (аналогічними) посадам апарату Національної поліції. Тобто згідно Переліку посад, затвердженого Наказом МВС від 17.02.2017 № 138 посади працівників міліції, які проходили службу у вищих навчальних закладах системи МBC прирівняні до посад поліцейських в органах Національної поліції різного рівня від апарату Національної поліції до апарату Головних управлінь Національної поліції, стройових підрозділів поліції. А Перелік посад поліцейських і військовослужбовців Національної гвардії України, які рівнозначні (аналогічні) посадам, що можуть бути заміщені поліцейськими і військовослужбовцями в державних органах, установах та організаціях, затверджений Наказом МВС України № 601 від 13.07.2018 передбачає прирівнювання посад працівників міліції, які проходили службу в навчальних закладах системи МВС України незалежно від рівня навчального закладу - да апарату Національної поліції України. Таким чином, зміст вищезазначеного Переліку дає підстави вважати необґрунтованим прирівнювання посад осіб начальницького та рядового складу органів внутрішніх справ (міліції), які проходили службу в навчальних закладах системи МВС до посад поліцейських в залежності від рівня навчального закладу при перерахунку пенсій колишнім працівникам міліції з 01.01.2016 року. Проведений нами аналіз нормативно-правових актів, які регламентують порядок перерахунку пенсій, свідчить про те, що розміри пен- 
сій після перерахунку у пенсіонерів, які мають однакову вислугу, звання і посаду, але проходили службу в різних підрозділах міліції відрізняються настільки, що така різниця складає половину пенсії, а в деяких випадках і набагато більше.

Інформація про середні розміри премій, що фактично виплачені за відповідними посадами поліцейських за січень 2016 року була направлена Міністерством внутрішніх справ України Головам ліквідаційних комісій ГУВС, УМВС України в областях листом 3261/05/22-2018 від 12 березня 2018 року «Про окремі питання підготовки та подання до органів Пенсійного фонду України довідок про грошове забезпечення для перерахунку пенсій» [10]. У зв'язку з тим, що середній розмір премій за відповідними посадами поліцейських згідно вищезазначеної інформації складає від 0.00 до 166 відсотків за різними посадами поліцейських, незрозумілим $\epsilon$ те, які чинники вплинули на такі розбіжності у розмірах премій. Розмір премій, які враховуються при обчисленні пенсії потребує детального правового врегулювання адже ст.43 Закону України «Про пенсійне забезпечення осіб, звільнених з військової служби, та деяких інших осіб» від 9 квітня 1992 року встановлює, що «Пенсії особам офіцерського складу, прапорщикам і мічманам, військовослужбовцям надстрокової служби та військової служби за контрактом, особам, які мають право на пенсію за цим Законом, та членам їх сімей обчислюються з розміру грошового забезпечення, враховуючи відповідні оклади за посадою, військовим (спеціальним) званням, процентну надбавку за вислугу років, щомісячні додаткові види грошового забезпечення (надбавки, доплати, підвищення) та премії в розмірах, установлених законодавством...» [11]. Також постановою Кабінету Міністрів від 11.11.2015 № 988 «Про грошове забезпечення поліцейських Національної поліції» передбачено право керівників органів, закладів та установ Національної поліції в межах затверджених для них асигнувань на грошове забезпечення здійснювати преміювання працівників. Але таке, на наш погляд, право при відсутності чітких критеріїв оцінювання результатів служби, призводить до необ'єктивності оцінювання служби конкретних працівників, а в деяких випадках - до зловживання службовим становищем. Крім того, на наш погляд, грошове забезпечення поліцейських повинно складатися з посадового окладу, окладу за спеціальне звання та відсоткової надбавки за вислугу років, розмір яких повинен містити більшу частину грошового забезпечення. Премії повинні бути встановлені за конкретні показники працівника у результати роботи органу, а їх розмір не повинен складати більшу частину грошового забезпечення. Що стосується врахування премій при перерахунку пенсії, то премія, як форма заохочення успіхів конкретного працівника у службі, не може ставитись в залежність від результатів роботи інших працівників чи визначатись, виходячи з усередненого показника, а повинна відповідати розміру фактичної премії за останньою штатною посадою, що бралась до розрахунку при оформленні пенсії. На думку Ладики Ю.В. оплата праці правоохоронців повинна бути не тільки пропорційною, та відповідати займаній посаді, але давати можливість присвятити себе своїй професії [13, с. 27].

Підсумовуючи викладене нами, можна зробити наступні висновки:
1. Питання про прирівнювання посад колишніх працівників міліції до посад поліцейських та перерахунку ім пенсії потребує більш детального вивчення, адже мова йде не тільки про справедливість при розподіленні соціальних благ, але й про законність і обґрунтованість виплат з Пенсійного Фонду України, який формується як із обов'язкових внесків суб'єктів господарювання і громадян, так і коштів Державного бюджету України, призначених для виплати пенсій військовослужбовцям та деяким іншим категоріям осіб. Ми пропонуємо посади колишніх працівників міліції, які проходили службу у вищих навчальних закладах системи МВС (академіі, університету, інституту), прирівняти до посад апарату Національної поліції України.

2. На підставі того, що натепер більшу частину грошового забезпечення поліцейських складають доплати, підвищення та премії, вважаємо за доцільне збільшити посадові оклади, оклади за спеціальним званням, відсоткову надбавку за вислугу років.

Що ж стосується премій та доплат, то вони повинні бути виплачені залежно від внеску кожного співробітника за результати роботи органу, а їх розмір не повинен складати більшу частину грошового забезпечення.

Порядок нарахування премій та їх виплата потребує детального правового регулювання - необхідно прийняти нормативний акт, який би встановлював конкретні підстави виплат та критерії розміру премій.

\section{Література}

1. Коваленко Н. Про право співробітників органів внутрішніх справ на перерахунок пенсії. Публічна служба і адміністративне судочинство: здобутки і виклики: збірник матеріалів Міжнар. наук.-практ. конф. (м. Київ, 5-6 липня 2018 р.) Київ. 2018. С. 162-167.

2. Вишновецька С.В. Основні теоретичні підходи до поняття соціальної безпеки. Правове забезпечення соціальної безпеки в умовах євроінтеграційних процесів: матеріали II Всеукр. наук.-практ. конф. (м. Київ, 26 жовтня 2018 р.). Київ. 2018. С. 14-17.

3. Про національну безпеку України: Закон України від 21.06.2018. № 2469-VIII. Офіційний вісник України. 2018. № 55. Ст. 1903.

4. Новікова О.Ф., Сидорчук О.Г., Панькова О.В та ін. Стан та перспективи соціальної безпеки в Україні: експертні оцінки: монографія. Львів: ЛРІДУ НАДУ, 2018. 184 с.

5. Кузьменко Г.В. Щодо розуміння соціальної безпеки. Правове забезпечення соціальної безпеки в умовах євроінтеграційних процесів: матеріали II Всеукр. наук.-практ. конф. (М. Київ, 26 жовтня 2018 р.). Київ. 2018. С. 22-28.

6. Князькова Л.М. Проблеми правового регулювання обчислення, виплати та перерахунку пенсій колишнім працівникам міліції. Правовий часопис Донбасу. 2018. № 2 (63). С. 50-54.

7. Перелік посад осіб начальницького i рядового складу органів внутрішніх справ України (міліції), які мають право на пенсійне забезпечення або одержують пенсію на умовах Закону України «Про пенсійне забезпечення осіб, звільнених з військової служби, та деяких інших осіб», що прирівнюються посадам поліцейських, затверджений Наказом МВС України від 17.02.2017 № 138. URL: http://zakon.rada.gov.ua/laws/show/z0348-17 (Дата звернення 28.05.2020).

8. Порядок проведення перерахунку пенсій, призначених відповідно до Закону України «Про пенсійне забезпечення осіб, звільнених з військової служби, та деяких інших осіб», затверджений постановою Кабінету Міністрів України від 13 лютого 2008 р. № 45. URL: https:// 


\section{та права соціального забезпечення}

zakon.rada.gov.ua/laws/show/45-2008-\%D0\%BF. (Дата звернення 28.05.2020).

9. Постанова Кабінету Міністрів № 988 від 11.11.2015 року «Про грошове забезпечення Поліцейських Національної поліції» URL: https://www.kmu.gov.ua/npas/ 248668490 (Дата звернення 28.05.2020).

10. Наказ МВС України № 601 від13.07.2018 року «Про затвердження Переліку посад поліцейських і військовослужбовців Національної гвардії України, які рівнозначні (аналогічні) посадам, що можуть бути заміщені поліцейськими і військовослужбовцями в державних органах, установах та організаціях. URL: http://search.ligazakon.ua/l_ doc2.nsf/link1/RE32354.html (Дата звернення 28.05.2020).

11. Лист МВС України від 12 березня 2018 року № 3261/05/22-2018. Додаток 6: Інформація про середні розміри премій, виплачених поліцейським за січень 2016. URL:http://veteran.mvs.gov.ua/news/79-schodo-dovidokpro-groshove-zabezpechennya-dlya-pererahunku-pensiy/ (Дата звернення 28.05.2020).

12. Про пенсійне забезпечення осіб, звільнених з військової служби, та деяких інших осіб: Закон України від 9 квітня 1992 року № 2262-XII. Відомості Верховної Ради України. 1992. № 29. Ст. 399.

13. Ладика Ю.В. Порівняльний аналіз забезпечення та реалізації соціальних гарантій працівників органів внутрішніх справ: зарубіжний та національний досвід. Науковий вісник Львівського університету внутрішніх справ. 2011. № 1 (2). С. 25-34.

Іванов І. В., кандидат юридичних наук, доцент, підполковник поліції, завідувач кафедри загально-правових дисциплін Донецького юридичного інституту Міністерства внутрішніх справ України

Князькова Л. М., кандидат юридичних наук, доцент, доцент кафедри загально-правових дисциплін Донецького юридичного інституту Міністерства внутрішніх справ України

Хайлова Т. В., кандидат наук з державного управління, доцент, доцент кафедри господарсько-правових дисциплін Донецького юридичного інституту Міністерства внутрішніх справ України 